Jurnal Pemikiran Masyarakat Ilmiah Berwawasan Agribisnis. 2017. 3(1): 40-52

\title{
ANALISIS EFISIENSI TEKNIS \\ USAHA TERNAK KAMBING PERANAKAN ETAWA \\ (Studi Kasus di Kelompok Agribisnis As-Salam Kota Tasikmalaya)
}

\author{
SITI MAEMUNAH \\ Dinas Pertanian dan Perikanan Kota Tasikmalaya \\ e-mail: aceu.new@gmail.com
}

DEDI SUFYADI

Fakultas Pertanian Universitas Siliwangi

IDA HODIYAH ${ }^{2}$

Fakultas Pertanian Universitas Siliwangi

\begin{abstract}
Abstrak
Tujuan penelitian ini adalah untuk mengetahui: (1) Faktor-faktor yang berpengaruh terhadap produksi susu kambing PE di Kelompok Peternak Agribisnis As-Salam., dan (2) Tingkat efisiensi teknis yang dicapai pada usaha ternak kambing PE di Kelompok Peternak Agribisnis As-Salam. Penelitian dilaksanakan dengan menggunakan studi kasus pada Kelompok Peternak Agribisnis As-Salam yang beranggotakan 26 orang dan keseluruhannya diambil sebagai sampel penelitian atau dilaksanakan sensus. Faktor-faktor yang berpengaruh terhadap produksi susu kambing PE dan tingkat efisiensi teknis yang dicapai pada usaha ternak kambing PE di Kelompok Peternak Agribisnis As-Salam dianalisis dengan menggunakan fungsi produksi frontier stokhastik dimana pendugaan parameter dilakukan dengan menggunakan software Front41. Hasil penelitian menunjukkan: (1) Faktor-faktor yang berpengaruh terhadap produksi susu kambing PE Kelompok Agribisnis As-Salam di Kota Tasikmalaya adalah jumlah kepemilikan ternak, tenaga kerja, pakan konsentrat dan obat-obatan. Sedangkan pakan hijauan tidak berpengaruh signifikan terhadap produksi susu kambing PE di Kota Tasikmalaya, dan (2) Tingkat efisiensi teknis yang dicapai pada usaha ternak kambing PE Kelompok Agribisnis As-Salam di Kota Tasikmalaya berkisar antara 39,78\% sampai dengan 99,04\% dengan rata-rata sebesar 77,46\%. Peternak yang mencapai efisiensi teknis di atas 70\% sebanyak 17 orang, sedangkan yang mencapai efisiensi teknis di bawah atau sama dengan $70 \%$ sebanyak 9 orang.
\end{abstract}

Kata kunci: Kambing PE, Fungsi Produksi, Efisiensi Teknis

\begin{abstract}
The purpose of this study was to determine: (1) The factors that affect the production of PE goats in Agribusiness Farmers Group As-Salam, and (2) The level of technical efficiency is achieved on PE goat raising in Agribusiness Farmers Group As-Salam. The research was conducted by using a case study on agribusiness farmer group As-Salam consisting of 26 people and all of them were taken as a sample or census conducted. Factors that affect the production of milk goats and technical efficiency levels achieved on PE goat raising in Agribusiness Farmers Group As-Salam analyzed using stochastic frontier production function where the parameter estimation is done using software Front41. The results showed: (1) The factors that affect the production of milk PE goats in Agribusiness Farmers Group As-Salam is the number of livestock ownership, labor, feed
\end{abstract}


Analisis Efisiensi Teknis Usaha Ternak Kambing Peranakan Etawa

(Studi Kasus di Kelompok Agribisnis As-Salam Kota Tasikmalaya)

SITI MAEMUNAH, DEDI SUFYADI, IDA HODIYAH

concentrates and drugs. While forage no significant effect on PE goat milk production, and (2) The level of technical efficiency is achieved on PE goat raising in Agribusiness Farmers Group As-Salam ranged from $39.78 \%$ to $99.04 \%$ with an average of $77.46 \%$. Farmers who achieve technical efficiency above $70 \%$ as many as 17 people, while achieving technical efficiency below or equal to $70 \%$ as many as 9 peoples.

Keywords: PE Goat, Production Function, Technical Efficiency

\section{PENDAHULUAN}

Kambing Peranakan Ettawa (PE) merupakan tipe kambing lokal di Indonesia yang mempunyai prospek yang bagus dalam pertumbuhan untuk mendukung perekonomian petani lokal. Kambing PE di Indonesia umumnya dipelihara oleh peternak di perdesaan. Perhatian utama pada peternakan kambing PE adalah bagaimana cara meningkatkan populasi kambing PE, sehingga diperlukan upaya peningkatan produktivitas yang pada gilirannya akan meningkatkan pendapatan peternak (Sumartono, $d k k$., 2016). Mayoritas kambing dipelihara oleh peternak kecil yang dikarakteristikkan oleh pertanian subsisten dengan penggunaan input yang rendah (Assan, 2013).

Fokus utama pada peternakan di Indonesia adalah produksi dan produktivitas yang masih rendah dikaitkan dengan sistem usaha yang masih konvensional. Kondisi ini dikarakteristikkan dengan manajemen usahatani yang mengintegrasikan usahatani dan usaha ternak, melibatkan anggota keluarga, rendahnya skala kepemilikan ternak, rendahnya pengetahuan dan keterampilan peternak yang menyebabkan rendahnya produksi dan produktivitas pada peternakan di perdesaan (Guntoro, dkk., 2016).

$$
\text { Penelitian Alpízar }
$$

menunjukkan masih rendahnya efisiensi produksi pada rumah tangga petani. Namun demikian, efisiensi teknik tersebut dapat ditingkatkan melalui perbaikan infrastruktur dan peningkatan akses ke pasar, serta sumber informasi melalui pengembangan jaringan jalan, komunikasi dan pelayanan lainnya.

Setiap proses produksi memerlukan landasan teknis untuk menghasilkan output tertentu. Petani dihadapkan pada keadaan terbatasnya jumlah faktor produksi yang digunakan dalam usaha untuk mencapai tujuannya. Masalahnya adalah bagaimana petani dapat meningkatkan usaha pertanian, sedangkan mereka memiliki keterbatasan modal dan mesin. Untuk itu, diperlukan efisiensi skala produksi agar penggunaan faktor-faktor produksi dapat efisien sehingga keuntungan petani meningkat (Darwanto, 2010). 
Jurnal Pemikiran Masyarakat Ilmiah Berwawasan Agribisnis. 2017. 3(1): 40-52

Populasi kambing betina di Kota Tasikmalaya sebanyak 24.719 ekor dan jantan sebanyak 46.007 ekor. Populasi kambing terbanyak terdapat di Kecamatan Sariwangi dengan populasi sebanyak 2.538 ekor jantan dan 6.586 ekor betina. Dari jumlah total kambing tersebut, sekitar $40 \%$ merupakan kambing PE. Kambing PE telah dibudidayakan di Kota Tasikmalaya dengan tujuan utama sebagai penghasil susu kambing. Namun, usaha ternak kambing PE tersebut masih sebatas usaha sampingan dan belum dijadikan sebagai sumber pendapatan utama bagi peternak kambing PE (Anep, 2013).

Beberapa penelitian terdahulu menunjukkan hasil bahwa faktor-faktor yang berpengaruh terhadap produksi susu adalah jumlah kepemilikan ternak, lahan, tenaga kerja, pakan konsentrat, peralatan pemerahan dan biaya pengobatan (Lopez, et al, 2006); jumlah ternak, pakan, dan tenaga kerja (Cabrera, et al., 2010); pakan konsentrat dan biaya modal (Alemdar dan Yilmaz, 2011); tenaga kerja, jumlah ternak, pakan hijauan dan pakan konsentrat (Aisyah, 2012).

Berdasarkan uraian di atas, maka tujuan dari penelitian ini adalah untuk mengetahui: (1) Faktor-faktor yang berpengaruh terhadap produksi susu kambing PE di Kelompok Peternak
Agribisnis As-Salam., dan (2) Tingkat efisiensi teknis yang dicapai pada usaha ternak kambing PE di Kelompok Peternak Agribisnis As-Salam.

\section{METODE PENELITIAN}

Penelitian dilaksanakan dengan menggunakan studi kasus. Menurut Arikunto (2002), penelitian studi kasus adalah suatu penelitian yang dilakukan secara intensif, terinci dan mendalam terhadap suatu organisasi, lembaga atau gejala tertentu.

Data yang digunakan pada penelitian ini terdiri atas data primer dan data sekunder. Pengumpulan data primer melalui wawancara dengan menggunakan kuesioner yang telah dipersiapkan sebelumnya. Data sekunder diperoleh melalui penelusuran pustaka atau referensi, maupun data yang diperoleh dari dinas atau instansi terkait, antara lain kantor desa Sirnagalih dan kecamatan Indihiang, kantor Dinas Pertanian, Perikanan dan Kehutanan Kota Tasikmalaya, kantor BPS Kota Tasikmalaya, dan Bappeda Kota Tasikmalaya.

Kelompok Peternak Agribisnis AsSalam di Kelurahan Sirnagalih Kecamatan Indihiang Kota Tasikmalaya diambil secara sengaja sebagai sampel kelompok (purposive sampling) dengan 
pertimbangan bahwa kelompok tersebut telah meraih prestasi di tingkat provinsi dan nasional. Jumlah anggota Kelompok Peternak Agribisnis As-Salam sebanyak 26 orang, dan semuanya diambil sebagai sampel penelitian atau dilaksanakan sensus. Menurut Arikunto (2002), penentuan sampel penelitian menggunakan metode sensus jika jumlah sampel kurang dari 100 .

Variabel-variabel yang digunakan dalam penelitian ini dioperasionalisasikan sebagai berikut:

- Produksi susu (Y) adalah jumlah produksi susu kambing yang dihasilkan selama periode pemeliharaan, dan diukur dalam satuan botol (botol).

- Jumlah ternak kambing PE $\left(\mathrm{X}_{1}\right)$ adalah jumlah ternak kambing PE yang dimiliki oleh peternak, dan diukur dalam satuan ternak (ST).

- Tenaga kerja keluarga $\left(\mathrm{X}_{2}\right)$, adalah jumlah tenaga dalam keluarga yang digunakan dalam pemeliharaan ternak kambing PE selama periode pemeliharaan, yang diukur dalam satuan hari kerja setara pria (HKSP).

- Pakan hijauan $\left(X_{3}\right)$, adalah jumlah hijauan pakan ternak yang terdiri dari rumput lapangan dan daun-daunan yang diberikan kepada ternak kambing PE selama periode pemeliharaan, dan diukur dalam satuan kilogram $(\mathrm{kg})$.

- Pakan konsentrat $\left(\mathrm{X}_{4}\right)$, adalah jumlah konsentrat yang diberikan pada ternak kambing PE selama periode pemeliharaan, yang diukur dalam satuan kilogram $(\mathrm{kg})$.

- Obat-obatan $\left(\mathrm{X}_{5}\right)$, adalah jumlah obatobatan yang diberikan kepada ternak kambing PE selama periode pemeliharaan untuk tindakan pencegahan maupun pengobatan penyakit, baik yang diberikan oleh petugas maupun dibeli sendiri, yang diukur dalam satuan unit (unit).

- Efisiensi teknis (ET) yang dimaksud dalam penelitian ini adalah perbandingan antara faktor produksi (input) yang digunakan dalam usaha ternak kambing PE dengan output yang dihasilkan per unit ternak. Pengukuran efisiensi teknis usaha ternak kambing PE dilakukan melalui perbandingan angka indeks input yang digunakan dengan angka indeks output yang dihasilkan. Nilai indeks efisiensi teknis antara 0 dan 1 , atau " $0<\mathrm{ET}<1$ ". Semakin mendekati nilai 1 maka efisiensi teknis yang dicapai peternak semakin tinggi, dan sebaliknya.

Fungsi produksi frontier digunakan untuk menekankan kepada kondisi output 
Jurnal Pemikiran Masyarakat Ilmiah Berwawasan Agribisnis. 2017. 3(1): 40-52

maksimum yang dapat dihasilkan (Coelli, et al., 2005). Fungsi produksi frontier menggambarkan output maksimal yang dapat dihasilkan dalam suatu proses produksi.

Aigner, Lovell dan Schmidt (1977), dan Meeusen dan van den Broeck (1977), mengemukakan tentang fungsi produksi frontier stokhastik dimana ada penambahan kesalahan acak (random error), $\mathrm{v}_{\mathrm{i}}$, yang ditambahkan ke dalam variabel acak non-negatif, $\mathrm{u}_{\mathrm{i}}$, pada persamaan berikut:

$\ln \mathrm{y}=\mathrm{x}_{\mathrm{i}} \beta+\mathrm{v}_{\mathrm{i}}-\mathrm{u}_{\mathrm{i}}$

Kesalahan acak, $v_{i}$, untuk mengukur kesalahan dan faktor acak lainnya, seperti pengaruh cuaca, nasib, dan sebagainya, pada nilai dari variabel output, bersama dengan pengaruh kombinasi dari variabel input yang tidak bisa dispesifikasikan pada fungsi produksi.

Dengan menggunakan fungsi produksi Cobb-Douglass, maka pada penelitian ini digunakan model persamaan empiris dalam menentukan faktor-faktor yang mempengaruhi produksi susu pada usaha ternak kambing PE sebagai berikut:

$\ln \mathrm{Y}=\beta_{0}+\beta_{1} \ln \mathrm{X}_{1}+\beta_{2} \ln \mathrm{X}_{2}+\beta_{3} \ln \mathrm{X}_{3}$

$$
+\beta_{4} \ln X_{4}+\beta_{5} \ln X_{5}+v_{i}-u_{i}
$$

Dimana:

$\mathrm{Y}=$ Produksi susu (botol)

$\mathrm{X}_{1}=$ Jumlah ternak (ST)

$\mathrm{X}_{2}=$ Tenaga kerja dalam keluarga

$$
\begin{aligned}
& X_{3}=\text { Pakan hijauan }(\mathrm{kg}) \\
& X_{4}=\text { Pakan konsentrat }(\mathrm{kg}) \\
& X_{5}=\text { Obat-obatan (unit) } \\
& \beta=\text { Koefisien regresi }
\end{aligned}
$$

Pendugaan parameter menggunakan program Frontier versi 4.1c.

Pengukuran efisiensi teknis dari produksi usahatani untuk petani ke-i ditaksir dengan formulasi sebagai berikut (Coelli, et al, 1998):

$T E_{i}=\frac{Y_{i}}{Y_{i}^{*}}=\frac{\exp \left(x_{i} \beta+v_{i}-u_{i}\right.}{\exp \left(x_{i} \beta+v_{i}\right)}=\exp \left(-u_{i}\right)$

Dimana $y_{i}$ adalah produksi aktual dari pengamatan, dan $y_{i}^{*}$ adalah dugaan produksi frontier yang diperoleh dari fungsi produksi stokastik. Efisiensi untuk seorang petani berkisar antara nol dan satu yang mempunyai korelasi terbalik dengan tingkat inefisiensi teknis. Efisiensi teknis ini mengukur output dari perusahaan ke-i relatif terhadap output yang bisa diproduksi dengan perusahaan yang efisien penuh (fully-efficient) menggunakan input vektor yang sama. Nilai efisiensi teknis secara bersamaan dengan estimasi fungsi produksi frontier diperoleh dengan menggunakan program Frontier versi 4.1c.

\section{HASIL DAN PEMBAHASAN}

Estimasi Fungsi Produksi

Estimasi fungsi produksi frontier stokhastik dilakukan dengan menggunakan metode Maximum Likelihood Estimation 
(MLE) dimana pendugaan parameter dilakukan dengan menggunakan program
Frontier 4.1c sebagaimana disajikan pada Tabel 1.

Tabel 1. Hasil Estimasi Fungsi Produksi Frotier Stokastik dengan Metode MLE

\begin{tabular}{|l|c|r|r|r|}
\hline \multicolumn{1}{|c|}{ Variabel } & Parameter & Koefisien & Standar Error & \multicolumn{1}{c|}{ t-ratio } \\
\hline Konstanta & $\beta_{0}$ & 3,5000 & 0,8731 & $4,0084^{*}$ \\
Jumlah kepemilikan ternak & $\beta_{1}$ & 0,8926 & 0,2262 & $3,9451^{*}$ \\
Tenaga kerja & $\beta_{2}$ & $-0,5141$ & 0,2114 & $-2,4315^{* *}$ \\
Pakan hijauan & $\beta_{3}$ & $-0,3150$ & 0,2113 & $-1,4908$ \\
Pakan konsentrat & $\beta_{4}$ & 0,1964 & 0,0932 & $2,1085^{* *}$ \\
Obat-obatan & $\beta_{5}$ & 0,1738 & 0,0851 & $2,0421^{* *}$ \\
Sigma square & $\sigma^{2}$ & 0,0412 & 0,0213 & $2,3100^{* *}$ \\
Gamma & $\gamma$ & 0,9903 & 0,0514 & $19,2560^{*}$ \\
\hline Log likelihood function & $=15,9682$ \\
LR Test of the one-sided error & $=22,0354$ \\
\hline
\end{tabular}

Sumber: Analisis Data Primer, 2013

Keterangan: *,**, menunjukkan signifikansi pada $\alpha 1 \%(2,8314), 5 \%(2,0796)$

Nilai taksiran parameter $\gamma$ dalam model secara statistik berbeda dari nol dengan sangat signifikan. Statistik LRTest untuk parameter $\gamma$ sebesar 19,2560 yang lebih tinggi jika dibandingkan dengan nilai kritis pada Tabel Kodde dan Palm $\left(\chi_{1}^{2}=15,968\right)$, yang menunjukkan bahwa ada efek inefisiensi teknis dalam model yang bersifat stokhastik. Fakta ini menunjukkan bahwa peternak kambing PE di di Kota Tasikmalaya belum efisien secara penuh (full-efficient) dalam melaksanakan usahanya.

$\gamma$ merupakan rasio antara deviasi inefisiensi teknis (U) terhadap deviasi yang disebabkan oleh faktor acak (Vi). Nilai taksiran parameter $\gamma$ sebesar 0,9903 yang signifikan secara statistik menunjukkan bahwa lebih dari 99,03\% variasi output di antara usaha ternak kambing PE berkaitan dengan perbedaan yang disebabkan oleh inefisiensi teknis. Atau dengan kata lain, nilai $\gamma$ sebesar 0,9903 menunjukkan bahwa sekitar $99,03 \%$ variasi dalam output diatribusikan oleh pengaruh inefisiensi teknik, sedangkan $0,97 \%$ disebabkan oleh pengaruh acak (random effect).

Model ini memiliki LR galat satu sisi (LR test of the one-sided error) sebesar 22,0354 yang lebih besar dari pada Tabel Kodde dan Palm (1986) pada $\mathrm{a}=5 \%$ yaitu 15,968 . Ini berarti model fungsi produksi stochastic frontier yang diperoleh menunjukkan adanya keberadaan inefisiensi teknis pada model.

Tabel 1 menunjukkan bahwa variabel jumlah kepemilikan ternak, 
Jurnal Pemikiran Masyarakat Ilmiah Berwawasan Agribisnis. 2017. 3(1): 40-52

tenaga kerja, pakan konsentrat dan obatobatan berpengaruh signifikan terhadap produksi susu kambing PE, sedangkan variabel yang tidak berpengaruh signifikan adalah pakan hijauan.

Jumlah kepemilikan ternak berpengaruh sangat signifikan terhadap produksi susu kambing PE. Nilai koefisien jumlah kepemilikan ternak bertanda positif menunjukkan bahwa produksi susu dapat ditingkatkan jika ada peningkatan jumlah ternak yang dimiliki. Nilai koefisien jumlah kepemilikan ternak sebesar 0,8926 menunjukkan bahwa penambahan $10 \%$ jumlah kepemilikan ternak akan meningkatkan produksi susu sebesar 8,93\%. Hasil penelitian ini sesuai dengan hasil penelitian Aisyah (2012); Ashagidigbi, et al (2011); Oji \& Chukwuma (2007); Kipserem, et al (2011); Ike (2011); yang menunjukkan bahwa jumlah kepemilikan ternak berpengaruh sangat signifikan terhadap produksi.

Tenaga kerja keluarga berpengaruh signifikan terhadap produksi susu kambing PE. Nilai koefisien tenaga kerja bertanda negatif menunjukkan bahwa produksi susu dapat ditingkatkan jika ada pengurangan penggunaan tenaga kerja. Hasl ini menunjukkan kurangnya keterampilan teknis peternak dalam memelihara kambing PE. Nilai koefisien tenaga kerja sebesar $-0,5141$ menunjukkan bahwa pengurangan tenaga kerja sebesar $10 \%$ akan meningkatkan produksi susu sebesar 5,14\%. Hasil penelitian ini sesuai dengan hasil penelitian Ashagidigbi, et al (2011) yang menunjukkan bahwa tenaga kerja keluarga berpengaruh signifikan terhadap produksi.

Pakan hijauan ternak (rumput) tidak berpengaruh signifikan terhadap produksi susu kambing PE. Nilai koefisien pakan hijauan bertanda negatif menunjukkan bahwa produksi susu dapat ditingkatkan jika ada pengurangan pemberian pakan hijauan. Hal ini menunjukkan bahwa pakan hijauan yang diberikan mempunyai kandungan nutrisi yang lebih rendah dibandingkan dengan kebutuhan nutrisi yang diperlukan oleh kambing PE dalam memproduksi susu. Nilai koefisien pakan hijauan sebesar $-0,3150$ menunjukkan bahwa pengurangan $10 \%$ pakan hijauan akan meningkatkan produksi susu sebesar $3,50 \%$. Pakan hijauan ternak yang diberikan kepada kambing PE adalah rumput lapangan yang mempunyai kandungan protein rendah. Menurut Kushartono dan Iriani (2004), rumput lapangan mempunyai kandungan protein 
berkisar 6-8\%, sedangkan rumput unggul mempunyai kandungan protein $8-10 \%$.

Pakan konsentrat berpengaruh signifikan terhadap produksi susu kambing PE. Nilai koefisien pakan konsentrat bertanda positif menunjukkan bahwa produksi susu dapat ditingkatkan jika dilakukan penambahan penggunaan pakan konsentrat. Nilai koefisien pakan konsentrat sebesar 0,1964 menunjukkan bahwa penambahan pakan konsentrat sebanyak $10 \%$ akan meningkatkan produksi susu sebesar 1,96\%. Dengan demikian peternak mempunyai kesempatan untuk meningkatkan produksinya dengan cara meningkatkan jumlah pemberian pakan konsentrat, namun peternak perlu mempertimbangkan adanya kenaikan biaya produksi akibat penambahan penggunaan pakan konsentrat tersebut. Hasil penelitian ini sejalan dengan hasil penelitian dari Aisyah (2012); Isyanto (2013); yang menunjukkan bahwa pakan konsentrat berpengaruh signifikan terhadap produksi. Menurut Laryska dan Nurhajati (2013), pemberian pakan konsentrat yang memiliki nilai nutrisi lebih tinggi dari pada hijauan, ditujukan untuk memberikan peluang kepada ternak agar dapat memaksimalkan pertumbuhan atau meningkatkan produksi.
Obat-obatan berpengaruh signifikan terhadap produksi susu kambing PE. Nilai koefisien obat-obatan bertanda positif menunjukkan bahwa produksi susu dapat ditingkatkan jika ada penambahan penggunaan obat-obatan. Nilai koefisien obat-obatan sebesar 0,1738 menunjukkan bahwa penambahan $10 \%$ penggunaan obat-obatan akan meningkatkan produksi susu sebesar 1,74\%. Penggunaan obat-obatan dimaksudkan sebagai tindakan pencegahan maupun pengobatan penyakit sehingga produksi susu dapat lebih optimal jika kambing PE berada pada kondisi kesaehatan yang prima. Hasil penelitian ini sejalan dengan hasil penelitian dari Ashagidigbi, et al (2011); Isyanto (2013); Oji \& Chukwuma (2007); Kipserem, et al (2011); Ike (2011); yang menunjukkan bahwa obat-obatan berpengaruh signifikan terhadap produksi.

\section{Efisiensi Teknis Usaha Ternak Kambing PE}

Efisiensi teknis usaha ternak kambing PE dimaksudkan untuk mengukur berapa tingkat produksi yang dapat dicapai dari potensi produksi yang mungkin dapat dicapai oleh peternak. Estimasi efisiensi teknis usaha 
Jurnal Pemikiran Masyarakat Ilmiah Berwawasan Agribisnis. 2017. 3(1): 40-52

penggemukan kambing PE dilakukan dengan menggunakan program Frontier 4.1c dari Coelli, et al, (2005). Program Frontier 4.1c ini memiliki kelebihan, yaitu disamping dapat menganalisis fungsi produksi; juga sekaligus dapat menghitung efisiensi teknisnya. Hasil estimasi efisiensi teknis usaha ternak kambing PE dapat dilihat pada Tabel 2 dan secara visual dapat dilihat pada Gambar 1.

Tabel 2. Distribusi Efisiensi Teknik Usaha Ternak Kambing PE

\begin{tabular}{cc}
\hline $\begin{array}{c}\text { Range Efisiensi Teknis } \\
(\%)\end{array}$ & Frekuensi \\
\hline $41-50$ & 1 \\
$51-60$ & 4 \\
$61-70$ & 4 \\
$71-80$ & 6 \\
$81-90$ & 2 \\
$91-10$ & 9 \\
\hline
\end{tabular}

Rata-rata tingkat efisiensi teknis $=77,46$ Minimum $=39,78$

Maksimum $=99,04$

Sumber: Analisis Data Primer, 2016

Tabel 2 menunjukkan bahwa peternak yang mencapai efisiensi teknis di atas $70 \%$ sebanyak 17 orang, sedangkan yang mencapai efisiensi teknis di bawah atau sama dengan $70 \%$ sebanyak 9 orang. Menurut Coelli (1998), nilai indeks efisiensi teknis hasil analisis dikategorikan efisien secara teknis jika memberikan nilai dugaan yang lebih dari $70 \%$ sebagai batas efisien.
Nilai efisiensi teknis terendah yang dicapai oleh peternak sebesar 39,78\% dan tertinggi sebesar 99,04\%, dan rata-rata sebesar $77,46 \%$. Nilai efisiensi teknis ini menunjukkan bahwa secara rata-rata peternak kabing PE mampu mencapai $77,46 \%$ dari produksi potensial yang dihasilkan dengan input yang dikorbankan menggunakan teknologi yang ada. Hal ini menunjukkan indikasi bahwa dalam jangka pendek masih ada peluang bagi peternak untuk meningkatkan produksinya sebesar $22,54 \%$ dengan kisaran 0,96-60,22\% yang dapat dicapai dengan penerapan sistem pengelolaan yang terbaik menggunakan teknologi yang ada.

Rata-rata efisiensi teknis sebesar $77,46 \%$ menunjukkan adanya kesenjangan inefisiensi (inefficiency gap) sebesar 22,54\%. Implikasinya adalah bahwa $22,54 \%$ produksi yang lebih tinggi dapat dicapai tanpa menggunakan tambahan input, atau penggunaan input dapat dikurangi untuk mencapai tingkat output yang sama.

Nilai rata-rata efisiensi teknis yang diperoleh menunjukkan bahwa rata-rata peternak untuk dapat mencapai tingkat efisiensi teknis yang tertinggi yang dicapai oleh peternak lainnya, mereka dapat menghemat biaya sekitar $21,79 \%$ 
[1-(0,7746/0,9904)]. Dengan kata lain, peternak dengan efisiensi teknis terkecil dapat menghemat biaya sebesar $59,83 \%$
[1-(0,3978/0,9904)] untuk dapat mencapai efisiensi teknis tertinggi yang dicapai oleh peternak lainnya.

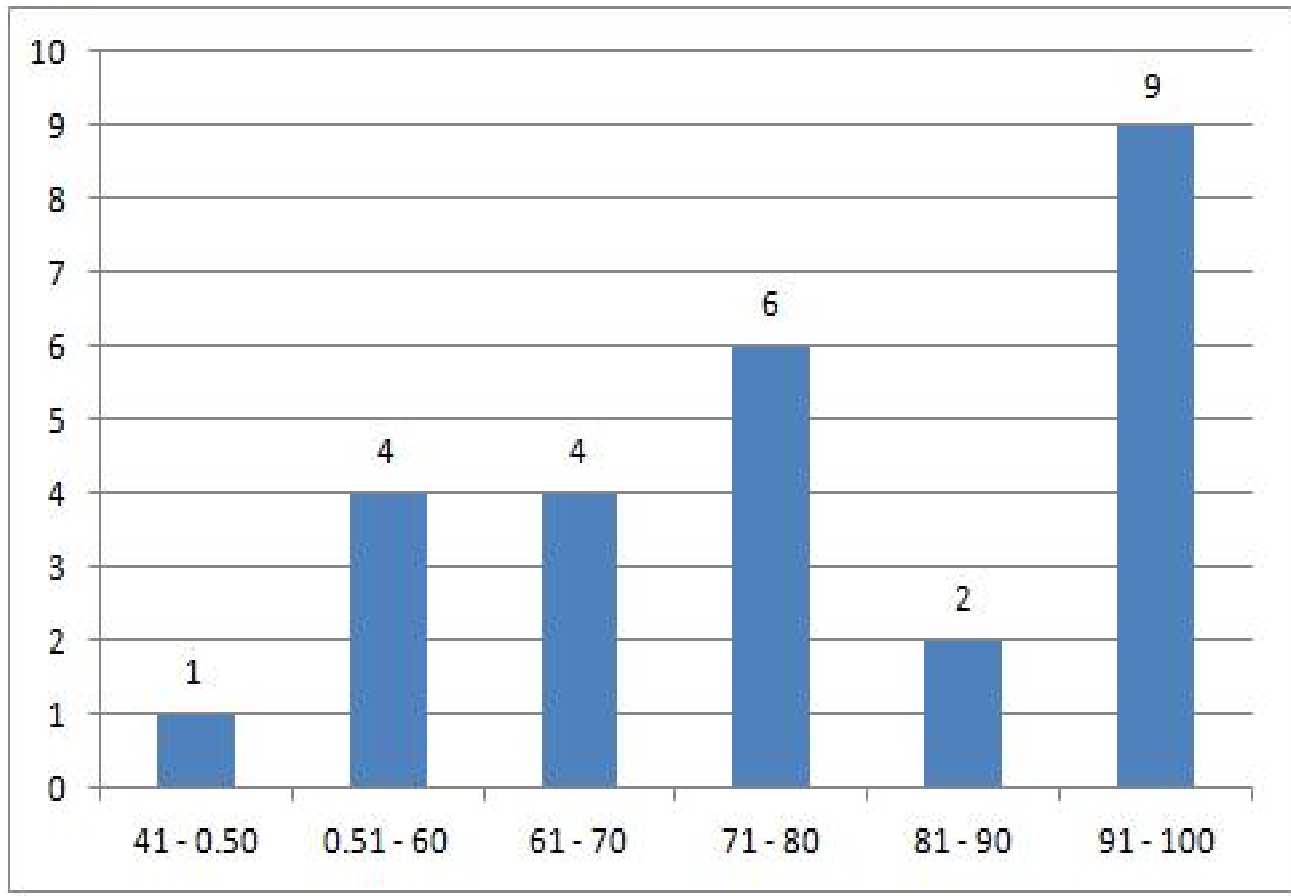

Gambar 1. Distribusi Efisiensi Teknik Usaha Ternak Kambing PE

Menurut Sukiyono (2004), perbedaan tingkat efisiensi teknik yang dicapai oleh petani mengindikasikan tingkat penguasaan dan aplikasi teknologi berusahatani yang berbeda-beda. Tingkat penguasaan teknologi yang berbeda disamping disebabkan oleh atribut yang melekat pada petani seperti tingkat pendidikan dan umur, juga disebabkan oleh faktor eksternal seperti kurangnya penyuluhan.

Belbase dan Grabowski (1985) dan Shapiro (1983) menyatakan bahwa usaha untuk meningkatkan efisiensi akan lebih efisien dari sisi biaya dibandingkan dengan introduksi teknologi baru sebagai sarana meningkatkan produktivitas pertanian, jika petani belum menggunakan teknologi yang efisien.

\section{PENUTUP}

Berdasarkan uraian di atas, maka dapat ditarik kesimpulan penelitian sebagai berikut:

(1) Faktor-faktor yang berpengaruh terhadap produksi susu kambing PE Kelompok Agribisnis As-Salam di Kota Tasikmalaya adalah jumlah 
Jurnal Pemikiran Masyarakat Ilmiah Berwawasan Agribisnis. 2017. 3(1): 40-52

kepemilikan ternak, tenaga kerja, pakan konsentrat dan obat-obatan. Sedangkan pakan hijauan tidak berpengaruh signifikan terhadap produksi susu kambing PE di Kota Tasikmalaya.

(2) Tingkat efisiensi teknis yang dicapai pada usaha ternak kambing $\mathrm{PE}$ Kelompok Agribisnis As-Salam di Kota Tasikmalaya berkisar antara $39,78 \%$ sampai dengan $99,04 \%$ dengan rata-rata sebesar $77,46 \%$. Peternak yang mencapai efisiensi teknis di atas 70\% sebanyak 17 orang, sedangkan yang mencapai efisiensi teknis di bawah atau sama dengan $70 \%$ sebanyak 9 orang.

Berdasarkan kesimpulan penelitian di atas, maka dapat diajukan rekomendasi kebijakan berupa: Upaya peningkatan efisiensi teknis pada usaha ternak kambing PE dapat dilakukan melalui peningkatan pengetahuan dan keterampilan teknis serta pengelolaan manajamen melalui pelaksanaan kegiatan penyuluhan, bimbingan teknis, pelatihan dan lain-lain yang akan meningkatkan produktivitas tenaga kerja peternak yang berdampak terhadap peningkatan produktivitas usaha ternak kambing PE.

\section{DAFTAR PUSTAKA}

Aigner, D.J., Lovell, C.A.K., dan Schmidt, P. 1977. Formulation and Estimation of Stochastic Frontier Production Function Models. Journal of Econometrics, 6(1): 2137.

Aisyah, S. 2012. Analisis Efisiensi Penggunaan Faktor-Faktor Produksi pada Usaha Ternak Sapi Perah Rakyat di Kecamatan Getasan Kabupaten Semarang. Economics Development Analysis Journal 1(1): 35-41.

Alpízar, C.A. 2007. Risk Coping Strategies and Rural Household Production Efficiency: QuasiExperimental Evidence From El Salvador. Disertasi. The Ohio State University.

Anep. 2013. Kambing Etawa: Budidaya di Tasik Potensial Tapi Belum Maksimal.

http://bandung.bisnis.com/read/201 30312/5/323313/kambing-etawabudidaya-di-tasik-potensial-tapibelum-maksimal. Diunduh tanggal 04 Juni 2016.

Arikunto, S. 2002. Prosedur Penelitian: Suatu Pendekatan Praktek. Edisi Revisi V. Jakarta: Rineka Cipta.

Ashagidigbi, W.M., Sulaiman, S.A., dan Adesiyan, A. 2011. Technical and Allocative Efficiency of Poultry Egg Producers in Nigeria. Agricultural Journal 6(4): 124-130.

Assan, N. 2013. Crossbreeding as a strategy to increase productivity in resource poor goat keepers in the rural areas of Zimbabwe. International Journal of Science and Knowledge 2(1): 52-56.

Belbase, K., dan Grabowski, R. 1985. Estimation of a Production Frontier Model: With Application to The Pastoral Zone of Eastern Australia. Australian Journal of Agricultural Economics 21: 169-179. 
Cabrera, V.E., Solis, D., dan del Corral, J. 2010. Determinants of Technical Efficiency Among Dairy Farms in Wisconsin. J. Dairy Science. 93: 387-393.

Coelli, T., Rao, D.S.P., dan Battese, G.E. 1998. An Introduction to Efficieny and Productivity Analysis. Kluwer Academic Publishers, BostonDordrecht-London.

. 2005. An Introduction to Efficieny and Productivity Analysis. Kluwer Academic Publishers, BostonDordrecht-London.

Darwanto. 2010. Analisis Efisiensi Usahatani Padi di Jawa Tengah (Penerapan Analisis Frontier). Jurnal Organisasi dan Manajemen 6(1): 46-57.

Guntoro, B., Rakhman, A.N., dan Suranindyah, $\quad$ Y.Y. 2016. Innovation Adoption of Dairy Goat Farmers in Yogyakarta, Indonesia. International Journal of Environmental \& Agriculture Research (IJOEAR) 2(2): 98-109.

Ike, P.C. 2011. Resource Use and Technical Efficiency of Small Scale Poultry Farmers in Enugu State, Nigeria: A Stochastic Frontier Analysis. International Journal of Poultry Science 10 (11): 895-898.

Isyanto, A.Y., dan Dehen, Y.A. 2013. Measurement of Farm Level Efficiency of Beef Cattle Fattening in West Java Province, Indonesia. Journal of Economics and Sustainable Development 4(10): 100-104.

Kushartono, B., dan Iriani, N. 2004. Inventarisasi Keanekaragaman Pakan Hijauan Guna Mendukung Sumber Pakan Ruminansia. Prosiding Temu Teknis Nasional Tenaga Fungsional Pertanian 2004. Pusat Penelitian dan Pengembangan Peternakan, Badan
Litbang Pertanian, Kementerian Pertanian. Hal. 66-71.

Laryska, N., dan Nurhajati, T. 2013. Peningkatan Kadar Lemak Susu Sapi Perah dengan Pemberian Pakan Konsentrat Komersial Dibandingkan dengan Ampas Tahu. Agroveteriner 1(2): 79-87.

Kipserem, J., Sulo, T., Chepng'eno, W., dan Korir, M. 2011. Analysis of Factors Affecting Dairy Goat Farming in Keiyo North and Keiyo South Districts of Kenya. Journal of Development and Agricultural Economics 3(11): 555-560.

Lopez, V.H.M, Bravo-Ureta, B.E., Arzubi, A., dan Schilder, E. 2006. Multi-output Technical Efficienciy for Argentinean Dairy Farms using Stochastic Production and Stochastic Distance Frontier wih Unbalanced Panel Data. Economic Agraria, Volumen 10 (2006).

Oji, U.O., dan Chukwuma, A.A. 2007. Technical Efficiency of Small Scale-Egg Production in Nigeria: Empirical Study of Poultry Farmers in Imo State, Nigeria. Research Journal of Poultry Science 1(3-4): 16-21.

Shapiro, K.H. 1983. Efficiency Differential in Peasant Agriculture and Their Implications for Development Policies. Journal of Development Studies 19: 179-190.

Sukiyono, K., 2004. Analisis Fungsi dan Efisensi Teknik: Aplikasi Fungsi Produksi Frontier pada Usahatani Cabai di Kecamatan Selupu Rejang Lebong, Kabupaten Rejang Lebong. Jurnal Ilmu-ilmu Pertanian Indonesia, 6(2): 104110.

Sumartono, Hartutik, Nuryadi dan Suyadi. 2016. Productivity Index of Etawah Crossbred Goats at Different Altitude in Lumajang District, East Java Province, 
Jurnal Pemikiran Masyarakat Ilmiah Berwawasan Agribisnis. 2017. 3(1): 40-52

Indonesia. IOSR Journal of Agriculture and Veterinary Science (IOSR-JAVS) 9(4): 24-30. 